\title{
Interest of Miscanthus x Giganteus in Phytomanaging Heavy Metal Contaminated Soils
}

\author{
Karim Al Souki, Brice Louvel, Francis Douay, Bertrand Pourrut \\ Yncrea - ISA Lille, Lille, France \\ karim.al-souki@yncrea.fr
}

\section{Extended Abstract}

For several decades, the area in Northern France surrounding the former lead $(\mathrm{Pb})$ smelter Metaleurop Nord, located at Noyelles-Godault, had been suffering from the significant dust amounts emitted throughout years of production, until closedown in 2003. Eventually, agricultural soils were extremely contaminated with metals, by which $\mathrm{Cd}, \mathrm{Pb}$ and $\mathrm{Zn}$ concentrations were 20 to 50 times exceeding the regional background values and negatively affecting crop production, human health and ecosystem [1].

Remediating such polluted areas represents a great challenge because of the presence of multiple pollutants and the surface of the contamination $\left(120 \mathrm{~km}^{2}\right)$. Conventional methods are unsuitable for such large area, therefore the interest in phytomanagement techniques was arisen and specifically phytostabilisaton which aims to reduce metal mobility and bioavailability. The metal-tolerant plants are able to precipitate metals and/or induce metal complexes formation in the rhizosphere and/or accumulate them into their root tissues, thus reducing their translocation to aerial organs [2, 3]. For the Metaleurop site, the choice fell on Miscanthus x giganteus for their high contamination tolerance and root accumulation capacities, as well as their multiple utilization properties [4].

The current work aimed to determine the impact of miscanthus on restoring the functionality of polluted soils with gradient metal concentrations $(\mathrm{Cd}, \mathrm{Pb}$ and $\mathrm{Zn})$. For this purpose, ex situ experiment was led to study the effect of three different miscanthus cultivars on: i) soil physico-chemical parameters, ii) metals' environmental availability and iii) soil biological parameters (microbial biomass carbon $\mathrm{MBC}$, basal respiration BR fluorescein diacetate hydrolytic activities FDHA and certain enzymatic activities in the corresponding soils (acid phosphatase, laccase and urease).

Metal-contaminated soil samples were collected from the agricultural fields surrounding the former smelter and designated M200, M500, M750 and M900, corresponding to their approximate Pb concentrations ( $\mathrm{mg} \mathrm{kg}^{-1}$ soil), whereas uncontaminated sample "MC" considered as control originated from an agricultural field distant from the smelter. About $100 \mathrm{~kg}$ of each of the homogenized soils were distributed in five containers, to which M. x giganteus were transferred. In addition, to assess the plant capacity to stabilize metals and restore soil functionality, two other modalities were established: uncultivated covered pots " $\mathrm{C}$ " (aimed to prevent any spontaneous vegetation development) and an uncovered "UC" control pots $(n=5)$.

One year following cultivation, results reveal that the $\mathrm{pH}$ slightly varied in the miscanthus cultivated pots unlike the non-cultivated ones. The soil organic carbon concentration and cation exchange capacity increased whereas the available $\mathrm{P}_{2} \mathrm{O}_{5}$ and total nitrogen concentrations decreased in the cultivated pots. Meanwhile, a decrease in concentrations of Cd and $\mathrm{Zn}$ in the $\mathrm{CaCl}_{2}$ extractable fraction was witnessed in the planted soils. Finally, the miscanthus cultivated pots witnessed an increase in their corresponding MBC, BR and FDHA as well as the acid phosphatase, laccase and urease activities compared to the non-planted ones.

Altogether, results demonstrated the ability of Miscanthus x giganteus to limit risks by reducing metal bioavailable fractions while positively affecting the cultivated soil functionality. Thus, Miscanthus x giganteus is a promising plant to phytomanage polluted areas such as Metaleurop.

\section{References}

[1] C. Pruvot, F. Douay, H. Fourrier, C. Waterlot, "Heavy Metals in Soil, Crops and Grass as a Source of Human Exposure in the Former Mining Areas," J. Soils Sediments, vol. 6, no. 4, pp. 215-220, 2006. 
[2] M. T. Gomez-Sagasti, I. Alkorta, J. M. Becerril, L. Epelde, M. Anza, C. Garbisu, "Microbial Monitoring of the Recovery of Soil Quality During Heavy Metal Phytoremediation," Water Air Soil Pollut., vol. 223, no. 6, pp. 32493262, 2012.

[3] M. H. Wong, "Ecological restoration of mine degraded soils, with emphasis on metal contaminated soils," Chemosphere, vol. 50, no. 6, pp. 775-780, 2003.

[4] F. Nsanganwimana, B. Pourrut, M. Mench, F. Douay, "Suitability of Miscanthus species for managing inorganic and organic contaminated land and restoring ecosystem services. A review," J. Environ. Manage., vol. 143, no. 6, pp. 123-134, 2014. 